autoantibody to smooth muscle antigen (S.M.A.). Autoantibodies have not previously been reported in this disease.

A $3 \frac{1}{2}$-year-old girl was admitted to hospital with a six-months history of cough, exertional dyspnoea and cyanosis, and severe weight loss. On examination she was apyrexial, emaciated, and had marked intercostal indrawing but no added breath sounds. Chest $x$-rays showed a fine general mottling of both lung fields. Repeated sputum cultures for tubercle bacilli were negative, as was the Mantoux test. The haematological findings, including differential white cell counts and blood and bone marrow films, were normal. The serum aspartate aminotransferase (SGOT) level (54 units) was slightly elevated for the laboratory technique used and, on one occasion only, she had a raised alkaline phosphatase level (62 King-Armstrong units). All the other liver function tests were normal. Paper electrophoresis of the serum showed only a slightly raised $\alpha_{3}$-globulin level. However, estimation of the individual immunoglobulin levels showed a low IgA (<40 mg/100 ml) with normal IgM (248 mg/ $100 \mathrm{ml})$ and $\mathrm{IgG}(920 \mathrm{mg} / 100 \mathrm{ml})$ levels. Her serum was screened for autoantibodies by the recommended immunofluorescence technique ${ }^{3}$ and there was a strong reaction" $(+++)$ with S.M.A. A lung biopsy showed the classic histological appearance of alveolar proteinosis. Immunofluorescence studies of frozen tissue showed no abnormal deposition of immunoglobulins in the lung, nor could autoreactive lung-specific antibodies be demonstrated in her serum. Despite repeated bronchial lavage her condition deteriorated rapidly and she died 10 months after the onset of the illness. Permission for necropsy was refused.

This case demonstrates the two important (and possibly related) differences between the adult and childhood forms of alveolar proteinosis: (1) In children the disease has a strikingly more serious prognosis. Of the 23 patients reviewed by Colón, the majority died in less than one year, and by the second year the mortality was $100 \%$. In Davidson's review of 139 patients (135 of whom were adults) only 38 died from alveolar proteinosis or its complications, many living for several years and 34 recovering spontaneously. (2) In children the disease is associated with immunological abnormalities. In Davidson's comprehensive review of the adults no immunological abnormalities are reported, whereas in at least 13 out of the 24 childhood cases reported there is evidence of disordered immunity.

Interestingly, a low serum IgA level was the most consistent immunoglobulin abnormality found by Colón. As $\operatorname{IgA}$ is responsible for the local protection of muoussecreting epithelial surfaces it is possible that these dhildren have a lowered resistance to a normally innocuours organism, possibly a virus, which provokes the accumulation of pneumocytes and the excessive surfactant production which characterizes alveolar proteinosis.

Low serum IgA levels are also found in some cases of coeliac disease. ${ }^{5}$ Though no association between coeliac disease and alveolar proteinosis has been reported, in the majority of childhood cases there is very severe weight loss, usually associated with chronic diarrhoea. These symptoms are infrequent in the adult cases.

The presence of antibody to S.M.A. is particularly interesting in view of the recent work by Farrow et al. ${ }^{6}$ on the nature of S.M.A. They have shown it to be situated on microfilaments just beneath the surface membrane of certain cells. They suggest that the presence of serum antibodies to S.M.A in patients with liver disease is caused by viral damage to the liver cell exposing the microfilaments, thus allowing the (S.M.A.) antigen to become immunogenic. Since these mirofilaments have been observed in fetal lung tissue, it is possible that a similar pro cess could induce the production of S.M.A. in some lung diseases. In support of this such antibodies have been demonstrated in two patients with idiopathic pulmonary disease. ${ }^{78}$

The two-year mortality in children with alveolar proteinosis is $100 \%$ and in adult it is less than $20 \%$. It is possible that this is due to the differing immunological status of the two populations, that of the affected children being abnormal.-I am etc.

Department of Pathology,

Elizabeth S. Gray

1 Gough, J., British Medical Fournal, 1967, 1, 629. Colón, A. R., Lawrence, R. D., Mills, S. D.. and 'Connell, E. J., American

of Children, 1971, 121, 48

Beck, J. S., Association of Clinical Pathologists Broadsheet, 1971, no. 69.

Davidson, J. M., and Macleod, W. M., British Fourmal of Diseases of the Chest, 1969, 63, 13.
Crabbé, P. A., and Heremans, J. F., American fournal of Medicine, 1967, 42, 319. W. L. J., Holborow, E. J., and Brighto Lancaster Smith, M. J., Benson, M. K., and Strickland, I. D., Lancet, 1971, 1, 473. Mason, A. M. S., McIllmurray, M. B., Golding,
P. L., and Hughes, D. T. D., British Medical fournal, 1970, 4, 596 .

\section{Cancer and the Patient}

SIR,-I greatly enjoyed and endorse $\mathrm{Mr}$. Charles Wright's Personal View (6 October, p. 45) that, as in many other social situations and problems, we lag behind the United States in free, uninhibited communication. I am persuaded also that a principal barrier to good doctor/patient relations in Britain is often a lamentable failure on the part of doctors to take the time and trouble to explain in a humane and intelligible way what is wrong, what is to be done, and what it is likely that the future holds.

I have, nonetheless, a slight reservation regarding cancer. This frightening, primitive word seems to have inbuilt such a nightmarish image that many patients are unable to endure it, and so there are cases in which a tactful little charade is played out by doctor, parient, and family, all well aware that the illness is cancer, yet managing to diminish emotional suffering by refraining from referring to it in direct terms. It is ? pity that we do not have readily available ? less horrifying name; maybe "prolifera" would do.-I am, etc.,

Department of Pathology,

W. ARTHUR MACKEY

Royal Infirmary
Glasgow

SIR,-I was very interested in Mr. Charles Wright's Personal View (6 October, p. 45) and in the ensuing correspondence. During the whole of my active professional life I was particularly interested in the management of cancer-in my case, of the ear, nose, and throat-and for 25 years conducted a combined follow up clinic with my radiotherapy colleague. This long association enabled us to make an accurate long term assessment of the patient's reactions to his disease and its treatment.

I would entirely agree with $\mathrm{Mr}$. R. M. Kirk (20 October, p. 164) that, at any rate up till now, the vast majority of British patients do not wish to be told the diagnosis, and this attitute was well demonstrated over the years in the combined follow-up clinic To anyone but the most unintelligent radioherapy means only one thing, but nothing was ever said for some five or six years, after which a number of patients discussed the matter quite openly. By that time they realized that their chances of permanent recovery were good. In a clinic like ours the doctor/patient relationship was very close and friendly and I cannot remember any instance of a patient suggesting that he should have been told exactly what was the matter with him at the start.

My policy therefore was not to tell the patient unless he asked, and this I taught my students. On the other hand I also emphasized that, if a patient put the direct question, he must be told the truth. To lie to a patient is quite unjustifiable and morally wrong. It will destroy the confidence of both patient and relatives, though a slightly optimistic view of the prognosis could in some cases be permissible. I am surprised at the suggestion that British consultants habitually lie to their cancer patients, and do not believe that this is so. In my experience "going to pieces" very rarely occurred. There were two suicides in some 300 cases. One was a patient who had asked and been told the diagnosis and the other one who had not.

I am not submitting that the North American custom may not, in the long run, be right, but it will take the time to become accepted in this country and it would be a dangerous mistake to adopt it too suddenly.-I am, etc.,

Kingsbridge, Devon

J. W. S. LINDAHL

\section{Muscosal Ulceration in Coeliac Disease}

SIR,-We note the comments of Drs. P. F. Fitzpatrick and A. G. MacIver (1 September, p. 502) on our paper (28 July, p. 212). The diagnosis of coeliac disease was made in our patient as subtotal villous atrophy was present in two separate jejunal biopsy specimens taken at sites different from the ulcerated areas.

The differentiation of coliac disease with mucosal uloeration from ulcerative jejunitis may indeed be difficult; other authors have classified the same case in different ways. ${ }^{12}$ We believe the term ulcerative ieiunitis should include those cases in which the villous architecture of the jejunum at sites away from the ulcerated areas is normal; however, when subtotal villous atrophy is present a diagnosis of coeliac disease with ulceration should be made. There will remain cases in which the non-ulcerated jejunal mucosa shows partial villous atrophy or only patchy villous changes; the classificarion of these cases is difficult. A gluren challenge after healing has occurred may be of helo, but in our patient we were unwilling to carry this out in view of the severity of the initial illness. With regard to the failure to respond to gluten withdrawal, this has been noted previously in coeliac disease with $^{2}$ and without ${ }^{3}$ muoosal ulceration. Not only may the addition of corticosteroids initiate a response, ${ }^{3}$ but corticosteroids alone may produce partial or complete healing."

The possibility of Crohn's disease was considered, but despite an extensive search 
for granulomata in serial sections none were found. Further, we are not aware of subtotal villous atrophy ocourring in those parts of the jejunum otherwise uninvolved in small-intestinal Crohn's disease.-We are, etc.,

P. E. JONES

Medical Unit,

Mnedical Unit,
London W.C.1

M. H. GleEson

Royal Infirmary,

Manchester

1 Goulston, K. J., Skyring, A. P., and McGovern, 14, J7. Australasian Annals of Medicine, 1965, Bayless, T. M., Kapelowitz, R. F., Shelley, W. M., Ballinger, W. F., and Hendrix, T., Ne
England fournal of Medicine, 1967, 276, 996. 3 England Fournal of Medicine, 1967, 276, 996. 300 .

Wall, A. J., Douglas, A. P., Booth, C. C., and

\section{Seat Belts}

SIR,-As the proposer of the sucoessful motion at the Annual Representative Meeting at Folkestone in June on the need for improvement in the design of seat belts and the advisability of their compulsory use in cars (Supplement, 16 June, p. 94), I was gratified to see the letter from Mr. E. S. R. Hughes of Melbourne (29 September, p. 695) on the experience in Australia of the lowered mortality and reduced incidence of injuries resulting from their legislation.

How right Professor W. Gissane (30 June, p. 772) was in commending the action of the Australian legislature in introducing compulsory belt-wear! Let us hope that our own legislators will be as discerning and perspicacious. - I am, etc.,

London $\mathbf{W} .9$

R. COVE-SMItH

\section{Mypotension in Tetanus}

SIR,-I wos interested to read the article by Dr. J. L. Corbett and others (25 August, p. 423), and would like to make two sug gestions :

(1) Rather than leave the patients with an alarmingly low blood pressure for 15-20 minutes, to try immediate infusion of 500 $1,000 \mathrm{ml}$ of plasma or other fluid. A heart pumping at a control venous pressure of only 1-5 $\mathrm{mm} \mathrm{Hg}$ as described in case 1 can be expected to respond to increased filling pressure with an increase in cardiac output and blood pressure, because of Starling' law of the heart. Increasing the blood volume is more effective than head-down tilt, and is surely safer than giving alphabeta-, or ganglion-blocking drugs to patient with hypotension. Patients on mechanical ventilation are likely to need a greater than normal blood volume, especially if autonomic function is impaired.

(2) Why not keep the patients sedated as well as paralysed? Reflex depression with barbiturates, diazepam, droperidol, or narcotics may well prevent these episodes of hypertension, which are quite common during light general anaesthesia. Perhaps normal subjects, without tetanus, would react in a similar way to prolonged curarization and mechanical ventilation as these three patients. $\rightarrow$ am, etc.,

JAMES JUDSON
Hypergastrinaemia in Rheumatoid Arthritis

SIR,-We read with interest Dr. K. J. Fraser's reply (29 September, D. 696) to our preliminary communication (30 June, p. 752) concerning elevated concentrations of plasma gastrin in rheumatoid arthritis. Dr. Fraser's initial comments on our lack of awareness of the literature on the incidence of achlorhydria in rheumatoid arthritis are perhaps unfortunate as no reference is made to the work of Armstrong, 1 who demonstrated no increase in incidence of parietal cell autoantibody in rheumatoid arthritis. $\mathrm{He}$ also demonstrated the organ-specificity of the antibody by means of gastric function studies. The omission of reference to this work carried out in this centre is out of step with Dr. Fraser's kindness elsewhere in referring to our work in the field of Sjøgren's syndrome. We would like to point out in addition that the increased incidence of hypergastrinaemia may prove to be of mudh more fundamental importance if it is not due to gastric atrophy.

Our preliminary studies would suggest normal acid secretory status in rheumatoid arthritis in the presence of hypergastrinaemia, and recently have shown that the induction of adjuvant arthritis in rats is associated with a concomitant elevation of fasting plasma immunoreactive gastrin. ${ }^{2}$ The significano of these observations remains unclear to date, but it seems unlikely that they merely reflect the presence of atrophic gastritis.-We are, etc.,

PATRICK J. ROONEY William Carson Dick

Centre for Rheumatic Diseases,

Glasgow

Armstrong, E. M., Annals of the Rneumatic Diseases, 1967, 26, 499.

Rooney, P. J., Dick, w. C., Buchanan, K. D.,
and Imrie, R. C., Nature New Biology. In press.

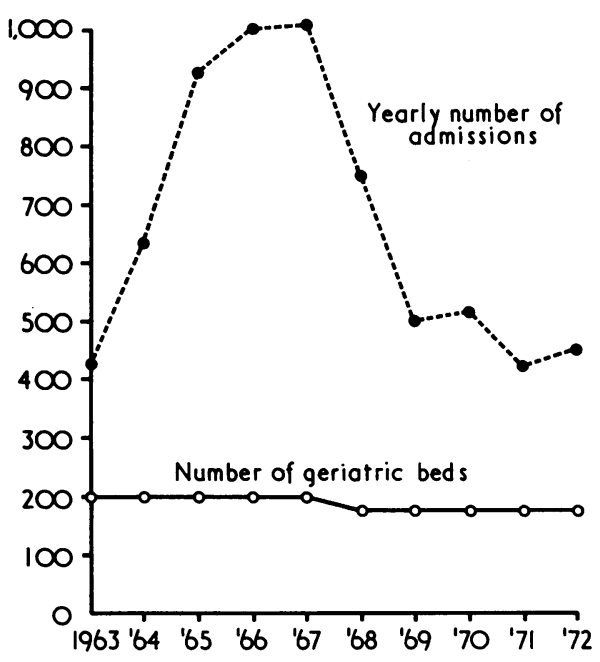

was overlooked was that the department had taken on a high long-stay commitment to help out other agencies under stress. There were 150 long-stay patients, including a 33bed psychogeriatric ward with demented patients who in many parts of the country would have been placed in a psychiatric hospital, and 26 patients had been accepted from welfare accommodation for whom Greenwioh would not normally have been the responsible geriatric hospital. There were therefore onily 50 admission and rehabilitation beds through which 1,000 admissions were passing each year. Within these 50 beds were about 25 very-high-turnover beds and about 25 slower-stream beds with a stay of three months or more before discharge, death, or transfier to long-stay accommodation. Clearly none of the long-stay or slowstream beds could be closed and the department was left with virtually no high turnover beds.

My choice in this situation was to accept preferentially those patients whose stay was likely to be short and to give low priority to those referrals who were likely to need a prolonged stay. Nevertheless, the department has functioned over the last five years as a low-turnover/long-waiting-list unit. In spite of not now taking ambulant demented patients and in spite of now adooting a "legalistic" approach to the geographical catchment area the number of long-stay patients is now 141 (the total bed number having fallen this year to 171). There are signs, however, that a new equilibrium is being established since the number of patients in other hospital beds waiting for transfer to the department has fallen from a maximum of 70 in 1972 to 20 in September 1973. During the whole period the staffing (medical, nursing, and paramedical) has remained substantially the same in numbers but, as would be expected, morale has plummeted.

The suggestion by Drs. Hodkinson and Jefferys that the work of a geriatric department is a matter of choice therefore appears to be an over-simplification. Given positive attitudes and adequate staffing, there appears to be a critical number of beds in any area with which a high-turnover/no-waiting-list service can be given. An important lesson that comes out of the Greenwich experience is that the total number of beds in a geriatric department is a misleading figure. In planning changes the number of admission and rehabilitation beds is a kev in beds would act as a stimulus to the efficiency of an over-bedded dercartment (200 beds for 18,000 over -65 population). What 